\title{
Single Factor Effect of Natural Deep Eutectic Solvent Citric Acid-Glucose Based Microwave-Assisted Extraction on Total Polyphenols Content from Mitragyna speciosa Korth. Havil Leaves
}

\author{
Herman 1,2, Arsyik Ibrahim², Bakti Puji Rahayu², M Arifuddin', Yuspian Nur', Wisnu Cahyo Prabowo', Maryono ${ }^{3}$, \\ Neneng Siti Silfi Ambarwati ${ }^{4}$, Laode Rijai ${ }^{1}$, Islamudin Ahmad ${ }^{1,2, *}$
}

Herman ${ }^{1,2}$, Arsyik Ibrahim², Bakti Puj Rahayu $^{2}$, M Arifuddin', Yuspian Nur ${ }^{1}$ Wisnu Cahyo Prabowo ${ }^{1}$, Maryono ${ }^{3}$ Neneng Siti Silfi Ambarwati ${ }^{4}$, Laode Rijai', Islamudin Ahmad $^{1,2, *}$

'Laboratory of Pharmaceutical Research and Development of TROPICAL PHARMACA, Faculty of Pharmacy, Universitas Mulawarman, Samarinda, 75119 East Kalimantan, INDONESIA. ${ }^{2}$ Department of Pharmaceutical Sciences, Faculty of Pharmacy, Universitas Mulawarman, Samarinda, 75119 East Kalimantan, INDONESIA. ${ }^{3}$ Department of Chemistry, Faculty of Mathematics and Natural Sciences, Universitas Negeri Makassar, Makassar, 90222 South Nulawesi, INDONESIA. ${ }^{4}$ Department of Cosmetology, Faculty of Engineering, Universitas Negeri Jakarta, East Jakarta, 13220 DKI Jakarta, INDONESIA.

\section{Correspondence}

Islamudin Ahmad

Laboratory of Pharmaceutical Research and Development of Tropical Pharmaca; Department of Pharmaceutical Sciences, Faculty of Pharmacy, Universitas Mulawarman, Samarinda, 75119 East Kalimantan, INDONESIA

Phone no: +6281342205060

E-mail: islamudinahmad@farmasi.unmul.ac.id History

- Submission Date: 12-06-2021;

- Review completed: 05-07-2021;

- Accepted Date: 09-07-2021.

DOI : 10.5530/pj.2021.13.143

Article Available online http://www.phcogj.com/v13/i5

Copyright

(C) 2021 Phcogj.Com. This is an openaccess article distributed under the term of the Creative Commons Attribution 4.0 International license.

\begin{abstract}
Applying green chemistry principles in the exploration of an active secondary metabolite from natura products has continued to experience a significant increase in the last decade, mainly natural deep eutectic solvent (NADES) usage. Mitragyna speciosa (Korth.) Havil (Rubiaceae family) is a native of East Kalimantan, which is traditionally used as an herb to treat headaches and inflammation by drinking boiled water a few leaves. On the other hand, this plant has an addictive effect. This study aims to determine the single factor effect of NADES citric acid-glucose-based microwave-assisted extraction (MAE) to obtain the yield of total polyphenols content (TPC) from M. speciosa leaves. Dried powder of M. speciosa leaves was extracted using NADES citric acid-glucose based MAE method with some different conditions such as NADES (citric acid-glucose) ratio $(4: 1,5: 1,6: 1 \mathrm{~g} / \mathrm{g}$ ), solid-liquid ratio $(10: 1,15: 1,20: 1 \mathrm{~mL} / \mathrm{g})$ microwave power $(90,270,450$ Watts), and extraction time $(15,20,25 \mathrm{~min})$. The determination of TPC was performed using Folin-Ciocalteau reagent and gallic acid as a standard with different concentration levels. The absorbance measured using spectrophotometer UV-VIS at $746 \mathrm{~nm}$ to obtain a regression formula of $Y=0.0022 X-0.00095$, where $R^{2}=0.9977$. Based on the result, the best of single factor condition effect was obtained the TPC value including NADES ratio of $248.69 \mathrm{mg}$ GAE/g sample $(5: 1 \mathrm{~g} / \mathrm{g}$ citric acid-glucose), a solid-liquid ratio of $146.93 \mathrm{mg} \mathrm{GAE} / \mathrm{g}$ sample $(15: 1 \mathrm{~mL} / \mathrm{g}$ solvent-sample), microwave power of $192.20 \mathrm{mg}$ GAE/g sample (270 Watts), and extraction time of $358.59 \mathrm{mg} \mathrm{GAE} / \mathrm{g}$ sample (15 min). The single factor effect of NADES citric acid-glucose-based MAE shows a difference in TPC value based on various conditions of this method.

Key words: Citric acid-glucose, Mitragyna speciosa (Korth.) Havil, Microwave-assisted extraction, Natura deep eutectic solvent, Total polyphenols content.
\end{abstract}

\section{INTRODUCTION}

In the last decade, natural deep eutectic solvents (NADES) have emerged as potential alternative solvents to replace conventional organic solvents, toxic, volatile, and flammable. NADES has been described as a product of hydrogen bonds of two different types of compounds. The appropriate concentration ratio can cause an intense depression at the melting point compared with the one of a single component state. ${ }^{1-4}$ NADES composition is derived from natural secondary metabolites such as amino acids, organic acids, amines, sugar alcohols, and sugars. It can also be combined with water with a certain number of molar ratios. NADES is formed based on the number and position of hydrogen bonds consisting of recipients of hydrogen bonds (HBA) and hydrogen bond donors (HBD). Both positions are very influential on the stability of NADES that are formed. In addition, the addition of water can affect properties such as biocompatibility, viscosity, conductivity, toxicity, and stability of the solvent. ${ }^{1-3,5-7}$

A combination of citric acid and glucose is one type of NADES composition and successfully utilized as a green solvent to extract the target secondary metabolites from natural products, mainly from plants. ${ }^{8,9}$ Some studies have reported applying this solvent type, such as extraction of total polyphenols and caffeine from coffee beans, ${ }^{10}$ extractions and determination of phenolics in Cajanus cajan leaves, ${ }^{11}$ and extraction and separation of main bioactive flavonoids from Radix Scutellariae. ${ }^{8}$ The use of NADES combined with non-conventional extraction methods has proven to be more effective than using conventional solvents because of its nonflammable, non-volatile, non-toxic, biodegradability, environmentally friendly, and edible. ${ }^{2,3,12}$

Mitragyna speciosa Korth. Havil (Rubiaceae family) is a native plant in Southeast Asia, mainly in Indonesia, Malaysia, Thailand, and Vietnam. ${ }^{13}$ In East Kalimantan, the local community uses this plant as an herb to treat headaches and inflammation by drinking boiled water a few leaves. Some studies of M. speciosa extract on rats are known to have an active anti-inflammatory of $200 \mathrm{mg} / \mathrm{kg}$. This plant contains several types of glycosides, rich in polyphenols and terpenoids. ${ }^{14,15,16}$ Besides, this plant has activities that can affect the central nervous system due to contains secondary metabolites that have addictive effects, such as mitragynine, 7-hydroxy-mitragynine, painantein, speciesiin, and speciosiliatin. ${ }^{17,18}$ Application of NADES bases microwave-assisted extraction has not been reported.

In the present study, a single factor effect of NADES based microwave-assisted extraction on total polyphenols content extraction from M. speciosa 
was performed using different combination factors to obtain the best extraction condition. This study aims to determine the single factor effect of NADES citric acid-glucose-based microwave-assisted extraction to obtain the yield of total polyphenols content from this plant.

\section{MATERIALS AND METHODS}

\section{Materials and equipment}

M. speciosa leaves were collected from Melak, West Kutai, East Kalimantan, Indonesia. The voucher specimen was identified at the Laboratory of Dendrology Faculty of Forestry, Universitas Mulawarman, Samarinda, East Kalimantan, Indonesia. Citric acid and sucrose were purchased from CV. Chlorogreen Bandung, West Java, Indonesia. Folin-Ciocalteau reagent, gallic acid standard, and sodium carbonate were purchased from Sigma Aldrich USA (via PT. Elo Karsa Utama, Indonesia). Meanwhile, the equipment was used, including Microwave domestic 900 Watts (Modena, USA), spectrophotometer UV-Vis, micropipette, and other glassware.

\section{EXTRACTION PROCESS}

\section{NADES Preparation}

In this study, a combination of citric acid and glucose as NADES (with three different ratios of 4:1, 5:1, and 6:1 g/g, respectively) were used according to the previous studies, ${ }^{10,19,20}$ with slight modification, Briefly, citric acid and glucose were weighed based on each different ratio. Both materials were melted at a specific temperature using a magnetic stirrer. After melting, aqua demineralization was added and homogenized. Subsequently, the obtained NADES solution was cooled at room temperature and filtered to obtain a homogeneous solution.

\section{NADES Based Microwave-Assisted Extraction}

A NADES citric acid-glucose-based microwave-assisted extraction was applied to obtain total polyphenols content (TPC) value from $M$. speciosa leaf using different condition factors based on some literature. ${ }^{9,10,19-24}$ Briefly, dried powder of $M$. speciosa leaf $(5 \mathrm{~g})$ was extracted using NADES citric acid-glucose base microwave-assisted extraction method using different conditions (including NADES ratio, solid-liquid ratio, microwave power, and extraction time) as can be seen in Table 1. Then, the extract solution and residue were separated using the Buchner funnel. The obtained extract solution was stored at room temperature and until ready to analyze.

\section{Determination of Total Polyphenols Content}

The total polyphenols content (TPC) value was determined using Folin-Ciocalteau reagent according to some literature. . $5,26,27,28,29,30,31$ The absorbance was measured using spectrophotometer UV-Vis at $746 \mathrm{~nm}$ with a bit of adjustment. Briefly, the standard and sample solution $(1 \mathrm{~mL})$ were mixed with $5 \mathrm{~mL}$ of distilled water and $0.5 \mathrm{ml}$ Folin-ciocalteau reagents, then homogenized for $5 \mathrm{~min}$. Subsequently, a $2 \mathrm{~mL} \mathrm{NaCO} 3$ solution was added and homogenized, and incubated for $30 \mathrm{~min}$ until ready to analyze. A standard solution of gallic acid with various concentrations from 12.5 to $200 \mu \mathrm{g} / \mathrm{mL}$ was used to obtain the

Table 1: Design experimental of single factor condition of NADES based microwave-assisted extraction on TPC value from M. speciosa leaves.

\begin{tabular}{lcccc} 
Factor variable & Unit & \multicolumn{3}{c}{ Range and level } \\
\cline { 3 - 5 } & & Low & Medium & High \\
NADES Ratio & $\mathrm{g} / \mathrm{g}$ & 4 & 5 & 6 \\
Solid - liquid ratio & $\mathrm{mL} / \mathrm{g}$ & 10 & 15 & 20 \\
Microwave Power & Watts & 90 & 270 & 450 \\
Extraction Time & Minutes & 10 & 15 & 20
\end{tabular}

linear regression formula of $\mathrm{Y}=0.0022 \mathrm{X}-0.00095$, where $\mathrm{R} 2=0.9977$. The TPC value of extract samples was determined using this formula.

\section{RESULTS AND DISCUSSION}

\section{Single Factor Experiment on Process}

In this study, an extraction method-based microwave-assisted extraction (MAE) was developed using a combination of citric acid and glucose as natural deep eutectic solvent (NADES) to extract the total polyphenol content from M. speciosa leaves. Based on studies that have been reported previously, ${ }^{8,10}$ some extraction condition factors (Table 1) that affect the ability to separate the target of secondary metabolite contained in the sample matrix. The extraction time and the microwave power can be adjusted to the modified domestic microwave device by adding a condenser to prevent the solvent from evaporating and reducing the pressure in the microwave during the extraction process. At the same time, the NADES ratio and the solid-liquid ratio were obtained from the combination of the two types of NADES and the comparison between samples and solvents. The use of NADES as an alternative solvent to replace conventional organic solvents because of its non-toxic nature, environmentally friendly, and inexpensive. ${ }^{3,32}$ The combination of the MAE method with NADES is very suitable for extracting polyphenol compounds in natural product plants.

Single Factor Effect of Natural Deep Eutectic Solventbased Microwave-Assisted Extraction on Total Polyphenols Content

\section{Effect of citric acid-glucose combination}

In the present study, citric acid-glucose with the ratio of $6: 1,5: 1$, and 4:1 $\mathrm{g} / \mathrm{g}$ were selected according to previous research, ${ }^{10}$ where both NADES components act as hydrogen bond acceptor (HBA) and hydrogen bond donor (HBD), respectively. ${ }^{33,34,35}$ The distilled water was added to accelerate NADES preparation and reduce viscosity. Meanwhile, other condition factors, such as solid-liquid ratio, microwave power, and extraction time, are carried out in constant form $(10: 1 \mathrm{~mL} / \mathrm{g}, 450$ watts, and $10 \mathrm{~min}$, respectively).

Table 2 shows the measurement results of total polyphenol levels from each extract obtained in the range of 200 to $250 \mathrm{mg} \mathrm{GAE} / \mathrm{g}$ sample. The three variations of the NADES concentration show that the 5:1 NADES ratio has a higher TPC value than the other ratios (Figure 1). It shows that the 5:1 g/g NADES ratio was the most optimum ratio, and these results were in accordance with studies that have been previously reported by Ahmad et al., $2018^{10}$ and Wei et al., 2015. ${ }^{11}$

\section{Effect of Solid-Liquid Ratio}

The solid-liquid ratio is the one-factor ratio between the number of solid samples (dried simplicia) and the solvent. This factor has an essential role during the extraction process and is related to the contact area between the sample (solid) and solvent (liquid) that affects extraction efficiency. The contact area can reach optimum conditions when the liquid phase is saturated to solid. The use of large quantities of solvents can cause improvidence and much waste, while the use of small amounts results in an incomplete extraction process. ${ }^{36,37}$

In this study, the ratio of $10: 1,15: 1$, and $20: 1 \mathrm{~mL} / \mathrm{g}$ with other factors in a constant state such as NADES ratio of $5: 1 \mathrm{~g} / \mathrm{g}$, extraction time of $10 \mathrm{~min}$, and microwave power of 450 Watts. As can be seen in Table 2 shows that the TPC value varies based on the difference in solid-liquid ratio. Optimum conditions were obtained at a solid-liquid ratio of 15:1 $\mathrm{mL} / \mathrm{g}$ (Figure 2). 
Table 2: Effect of Citric acid - glucose ratio on TPC value.

$\begin{array}{ccccc}\begin{array}{c}\text { Citric Acid- } \\ \begin{array}{c}\text { Glicose ratio } \\ (\mathbf{g} / \mathbf{g})\end{array}\end{array} & \text { Absorbance } & \begin{array}{c}\text { TPC } \\ (\mathrm{mgGAE} / \mathrm{g})\end{array} & \begin{array}{c}\text { Average TPC } \\ (\mathrm{mgGAE} / \mathrm{g})\end{array} & \begin{array}{c}\text { Deviation } \\ \text { Standard }\end{array} \\ 4: 1 & 0.075 & 228.08 & & \\ & 0.076 & 231.08 & 232.07 & 4.57 \\ & 0.078 & 237.06 & & \\ 5: 1 & 0.082 & 261.30 & & \\ & 0.076 & 242.39 & 248.69 & \\ & 0.076 & 242.39 & & 2.92 \\ 6: 1 & 0.069 & 199.42 & & \\ & 0.071 & 205.13 & 203.23 & \\ & 0.071 & 205.13 & & \\ \end{array}$

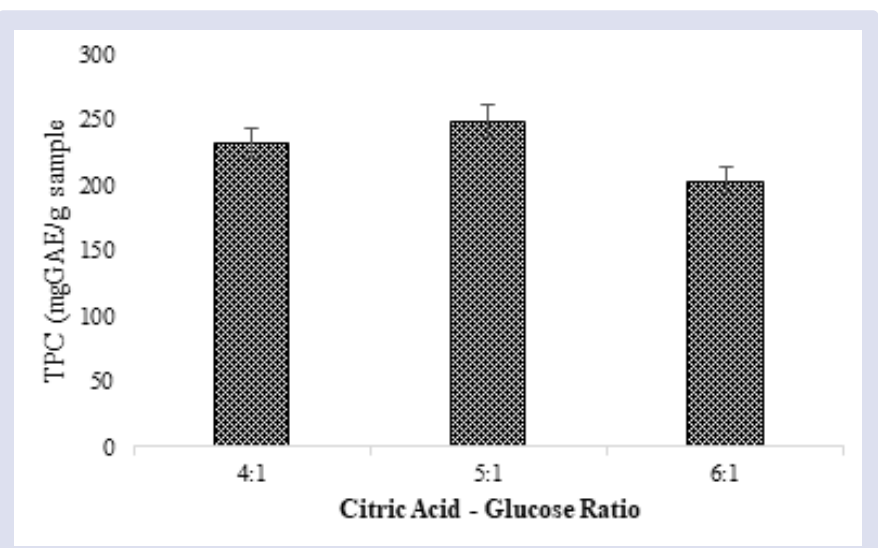

Figure 1: The optimum single factor of NADES composition ratio on polyphenols extraction from $M$. speciosa leaves.

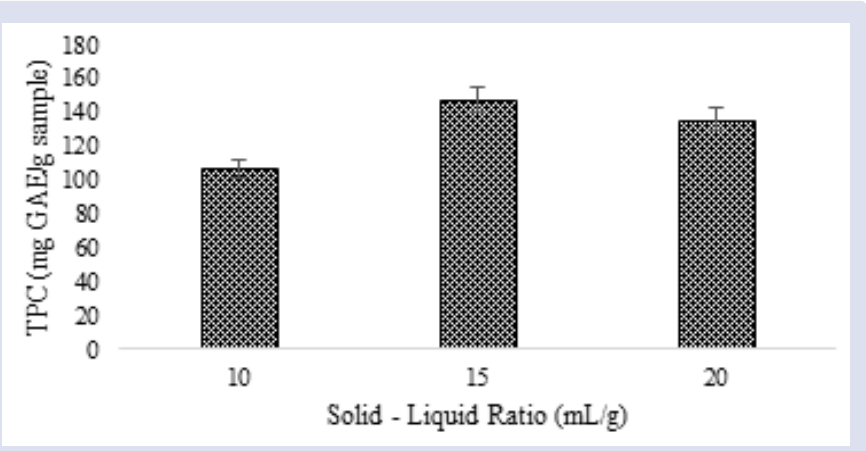

Figure 2: The optimum single factor condition of solid-liquid ratio on polyphenol extraction from $M$. speciosa leaves.

\section{Effect of Microwave Power}

The microwave power from the microwave-assisted extraction method can affect the rate of equilibrium and interactions between solvents and solutes (secondary metabolites) in the sample matrix and control the partition of solutes between the sample and the extraction phase. ${ }^{33}$ To determine the effect of microwave power on the extraction efficiency of TPC, extraction was carried out at 90, 270, and 450 Watts, respectively, with an of $10 \mathrm{~min}$ extraction time, 5:1 g/g NADES ratio, and the solidliquid ratio of $10: 1 \mathrm{~mL} / \mathrm{g}$ sample.

The results obtained (Table 4) show that the microwave power from 90 to 270 watts has an increased TPC value. This is due to the separation of the secondary metabolite constituents from the sample matrix due to the increase in temperature and pressure due to the microwave power. In contrast, the microwave power of 270 to $450 \mathrm{~W}$ atts tends to decrease due to the possibility of secondary metabolite compounds being damaged due to excessive temperature and pressure. Figure 3 shows the optimum TPC value at 270 watts of microwave power because, in these conditions, there is an equilibrium between temperature and microwave pressure with the extraction process.

\section{Effect of Extraction Time}

In Table 5, the effect of extraction time was performed using different the time include 10,15 , and $20 \mathrm{~min}$. In range $10-15$ minutes of the efficiency of extraction time shows a tendency to increase in TPC value. The phenomenon indicates that an increase in extraction time can cause an acceleration of the mass transfer of the analyte and a decrease in the viscosity of the extraction solvent. ${ }^{38,39}$ Whereas, if the extraction time was extended by more than $15 \mathrm{~min}$ (precisely for $20 \mathrm{~min}$ ), the TPC value has decreased. This was due to the high microwave power, and the longer extraction time can damage the structure of the components of the target secondary metabolite. ${ }^{40}$ Therefore, According to Figure 4 shows that the optimum extraction time is obtained at the $15^{\text {th }} \mathrm{min}$.

Based on this study's result, the single factor effect of NADES citric acid-glucose-based microwave-assisted extraction with different conditions includes NADES ratio, solid-liquid ratio, microwave power, and extraction time. These results are preliminary data to optimize the

Table 3: Effect of Solid-Liquid Ratio on TPC value.

\begin{tabular}{lllll}
\hline $\begin{array}{l}\text { Solid-Liquid } \\
\text { ratio }(\mathrm{mL} / \mathrm{g})\end{array}$ & Absorbance & $\begin{array}{l}\text { TPC } \\
(\mathrm{mgGAE} / \mathrm{g})\end{array}$ & $\begin{array}{l}\text { Average TPC } \\
(\mathrm{mgGAE} / \mathrm{g})\end{array}$ & $\begin{array}{l}\text { Deviation } \\
\text { Standard }\end{array}$ \\
\hline \multirow{2}{*}{$10: 1$} & 0.057 & 107.25 & & \\
& 0.056 & 105.39 & 106.63 & 1.071 \\
& 0.057 & 107.25 & & \\
& 0.035 & 158.70 & & 11.113 \\
$15: 1$ & 0.030 & 136.62 & 146.93 & \\
& 0.044 & 145.45 & & 12.657 \\
& 0.023 & 145.59 & & \\
$20: 1$ & 0.019 & 121.27 & 135.457 & \\
& 0.055 & 139.51 & & \\
\end{tabular}

Table 4: Effect of different microwave power on TPC value.

\begin{tabular}{|lllll}
$\begin{array}{l}\text { Microwave } \\
\text { Power (Watt) }\end{array}$ & Absorbance & $\begin{array}{l}\text { TPC } \\
(\mathrm{mgGAE} / \mathrm{g})\end{array}$ & $\begin{array}{l}\text { Average TPC } \\
(\mathrm{mgGAE} / \mathrm{g})\end{array}$ & $\begin{array}{l}\text { Deviation } \\
\text { Standard }\end{array}$ \\
\hline \multirow{4}{*}{90} & 0.051 & 175.95 & & \\
& 0.041 & 142.08 & 156.76 & 17.383 \\
& 0.053 & 152.24 & & \\
270 & 0.065 & 194.16 & & \\
& 0.063 & 188.28 & 192.20 & 3.399 \\
& 0.065 & 194.16 & & \\
450 & 0.059 & 188.84 & & \\
& 0.048 & 154.20 & 185.69 & 30.048 \\
& 0.058 & 214.04 & & \\
\hline
\end{tabular}

Table 5: Effect of different extraction time on TPC value.

\begin{tabular}{lllll}
$\begin{array}{l}\text { Extraction } \\
\begin{array}{l}\text { Time } \\
\text { (Minutes) }\end{array}\end{array}$ & Absorbance & $\begin{array}{l}\text { TPC } \\
(\mathrm{mgGAE} / \mathrm{g})\end{array}$ & $\begin{array}{l}\text { Average TPC } \\
\text { (mgGAE/g) }\end{array}$ & $\begin{array}{l}\text { Deviation } \\
\text { Standard }\end{array}$ \\
\hline \multirow{2}{*}{10} & 0.043 & 194.09 & & 15.922 \\
& 0.036 & 163.18 & 176.42 & \\
& 0.038 & 172.01 & & \\
15 & 0.085 & 371.56 & & \\
& 0.080 & 349.94 & 358.59 & 11.438 \\
& 0.081 & 354.26 & & \\
20 & 0.039 & 194.09 & & \\
& 0.037 & 163.18 & 173.48 & \\
& 0.036 & 173.261 & & \\
& & & &
\end{tabular}




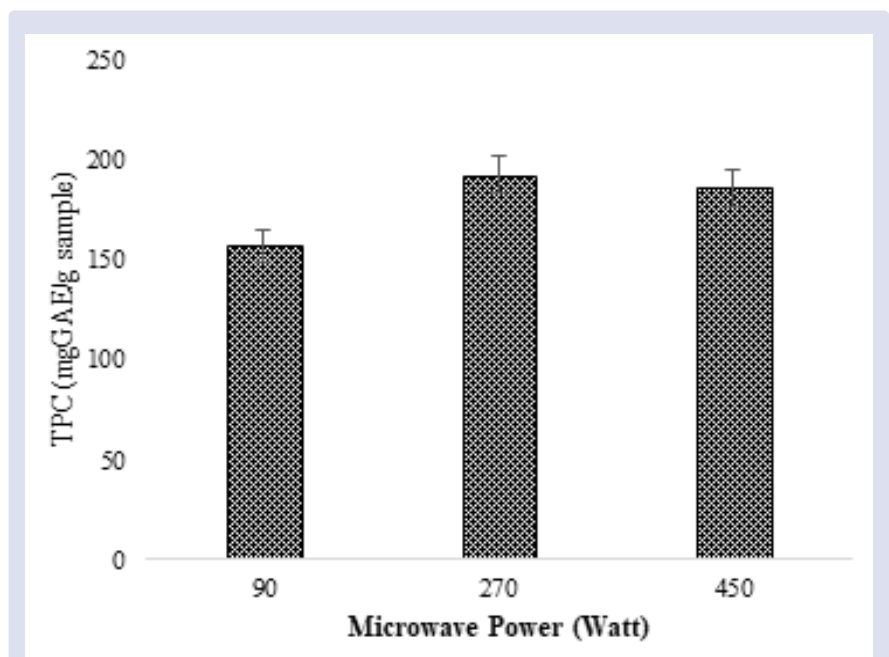

Figure 3: The optimum single factor condition of microwave power on polyphenols extraction from $M$. speciosa.

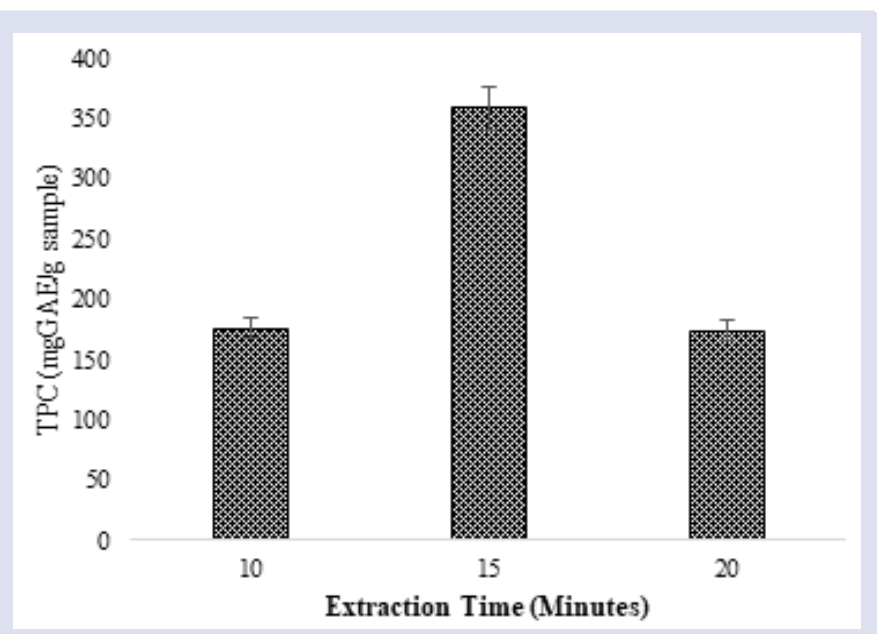

Figure 4: The optimum single factor of extraction time on polyphenolics extraction from $M$. speciose.

extraction method using the NADES based on microwave-assisted extraction method to obtain the optimum target secondary metabolite from $M$. speciosa leaves quickly, easily, efficiently, and environmentally friendly.

\section{ACKNOWLEDGMENTS}

This study was funded and supported by the Ministry of Research, Technology, and Higher Education, Republic of Indonesia and Institute of Research and Community Service, Universitas Mulawarman (LP2M UNMUL) via a grant "Hibah Penelitian Dasar Unggulan Perguruan Tinggi (PDUPT) 2019- 2020.

\section{CONFLICTS OF INTEREST}

The authors declared no conflicts of interest.

\section{REFERENCES}

1. Bubalo MC, Vidovi S, Radoj I, and Joki S. Green solvents for green technologies. Journal of Chemistry Technology and Biotechnology. 2015; 90: 1631-1639.

2. Castro VIB, Craveiro R, Silva JM, Reis RL, Paive A, and Duarte ARC. Natural deep eutectic systems as alternative nontoxic cryoprotective agents. Cryobiology. 2018; 83: 15-26.
3. Gomez FJV and Espino M. A greener approach to prepare natura deep eutectic solvents. Analitical Chemistry. 2018; 3: 6122-6125.

4. Martins MAR, Pinho SP, Coutinho JAP. Insights into the nature of eutectic and deep eutectic mixtures. Journal of Solution Chemistry. 2019; 48(7): 962-982.

5. Craveiro R, Aroso I, Flammia V, Carvalho T, Viciosa MT, Dionisio $M$, Barreiros S, Reis RL, Duarte ARC, and Paiva A. Properties and thermal behavior of natural deep eutectic solvents. Journal of Molecular Liquids. 2016; 215: 534-540.

6. Dai Y, Witkamp GJ, Verpoorte R, and Choi YH. Tailoring properties of natural deep eutectic solvents with water to facilitate their applications. Food Chemistry. 2015; 187: 14-19.

7. Dwamena A. Recent advances in hydrophobic deep eutectic solvents for extraction. Separations. 2019; 6(1): 1-15.

8. Wei ZF, Wang $X Q$, Peng $X$, Wang $W$, Zhao CJ, Zu YG, and Fu YJ. Fast and green extraction and separation of main bioactive flavonoids from Radix Scutellariae. Industrial Crops and Products. 2015; 63: 175-181.

9. Savi L, Dias M, Carpine D, Waszcynskyj N, Ribani R, and Haminiuk C. Natural deep eutectic solvents (NADES) based on citric acid and sucrose as a potential green technology : a comprehensive study of water inclusion and its effect on thermal, physical and rheological properties. International Journal of Food Science and Technology. 2018; 54(3): 898-907.

10. Ahmad I, Pertiwi AS, Kembaren YH, Rahman A, and Mun'in A Application of natural deep eutectic solvent-based ultrasonic assisted extraction of total polyphenolic and caffeine content from Coffe Beans (Coffea Beans L.) for instant food products. Journal Applied of Pharmaceutical Sciences. 2018; 8(8): 138-143.

11. Wei Z, Qi X, Li T, Luo M, Wang W, Zu Y, and Fu Y. Application of natural deep eutectic solvents for extraction and determination of phenolics in Cajanus cajan leaves by ultra performance liquid chromatography. Separation and Purification Technology. 2015; 149: 237-244.

12. Duarte ARC, Ferreira ASD, Barreiros S, Cabrita E, Reis RL, and Paiva A. A comparison between pure active pharmaceutical ingredients and therapeutic deep eutectic solvents: Solubility and permeability studies. European Journal of Pharmaceutics and Biopharmamecutics. 2017; 114: 296-304.

13. Ahmad K and Aziz Z. Mitragyna speciosa use in the northern states of Malaysia: A cross-sectional study. Journal of Ethnopharmacology. 2012; 141(1): 446-450.

14. Chittrakarn S, Keawpradub N, Sawangjaroen K, Kansenalak S and Janchawee B. The neuromuscular blockade produced by pure alkaloid, mitragynine and methanol extract of kratom leaves (Mitragyna speciosa Korth.). Journal of Ethnopharmacology. 2010; 129(3): 344-349.

15. Tohar N, Shilpi JA, Sivasothy Y, Ahmad S and Awang K. Chemical constituents and nitric oxide inhibitory activity of supercritical carbon dioxide extracts from Mitragyna speciosa leaves. Arabian Journal of Chemistry. 2016; 12(3): 350-359.

16. Brown PN, Lund JA and Murch SJ. A botanical, phytochemical and ethnomedicinal review of the genus Mitragyna korth: Implications for products sold as kratom. Journal of Ethnopharmacology. 2017; 202: 302-325.

17. Horie S, Koyama F, Takayama H, Ishikawa H, Aimi N, Ponglux D, Matsumoto K, and Murayama T. Indole alkaloids of a Thai medicinal herb, Mitragyna speciosa, that has opioid agonistic effect in guineapig ileum. Planta Medica. 2005; 71(3): 231-236.

18. Takayama H. Chemistry and pharmacology of analgesic indole alkaloids from the rubiaceous plant, Mitragyna speciosa. Chemical and Pharmaceutical Bulletin. 2004; 52(8): 916-928. 
19. Dai Y, van Spreonsen J, Vitkamp GJ, Verpoorte R, and Choi $\mathrm{YH}$. Ionic liquids and deep eutectic solvents in natural products research: Mixtures of solids as extraction solvents. Journal of Natural Products. 2013; 76(11): 2162-2173.

20. Dai Y, Witkamp GJ, Verpoorte R, and Choi YH. Natural deep eutectic solvents as a new extraction media for phenolic metabolites in Carthamus tinctorius L. Analytical Chemistry. 2013; 85(13): 6272 6278.

21. Cui $Q$, Peng $X$, Yao XH, Wei ZF, Luo $M$, Wang W, Xhao CJ, Fu $Y F$, and Zu YG. Deep eutectic solvent-based microwave-assisted extraction of genistin, genistein and apigenin from pigeon pea roots. Separation and Purification Technolology. 2015; 150: 63-72.

22. Ahmad I, Yanuar A, Mulia K, and Mun'im A. Extraction of polyphenolic content from Peperomia pellucida (L) Kunth herb with 1-ethyl-3- methylimidazolium bromide as a green solvent. Indian Journal of Pharmaceutical Sciences. 2017; 79(6): 1013-1017.

23. Trinovita E, Sutriyo, Saputri FC, and Mun'im A. Enrichment of the gamma oryzanol level from Rice Bran by addition of inorganic salts on ionic liquid 1-butyl-3- methylimidazolium hexafluorophosphate ([BMIM]PF6) extraction. Journal of Young Pharmacists. 2017; 9(4): 555-558.

24. Mun'im A, Nurpriantia N, Setyaningsih R, and Syahdi RR. Optimization of microwave-assisted extraction of active compounds, antioxidant activity and angiotensin converting enzyme (ACE) inhibitory activity from Peperomia pellucida (L.) Kunth. Journal of Young Pharmacists. 2017; 9(1): 73-78.

25. Bobo-García G, Davidov-Pardo G, Arroqui C, Marín-Arroyo MR, and Navarro M. Intra-laboratory validation of microplate methods for total phenolic content and antioxidant activity on polyphenolic extracts, and comparison with conventional spectrophotometric methods. Journal of Science Food and Agriculture. 2014; 95(1): 204-209.

26. Margraf T, Karnopp AR, Rosso ND and Granato D. Comparison between Folin-Ciocalteu and Prussian Blue assays to estimate the total phenolic content of juices and teas using 96-Well microplates. Journal of Food Sciences. 2015; 80(11): 2397-2403.

27. Vongsak B, Sithisarn $\mathrm{P}$, and Mangmool S. Maximizing total phenolics, total flavonoids contents and antioxidant activity of Moringa oleifera leaf extract by the appropriate extraction method. Industrial Crops and Products. 201; 44: 566-571.

28. Tawaha K, Alali FQ, Gharaibeh M, Mohammad M, El-Elimat T, and Elelimat T. Antioxidant activity and total phenolic content of selected Jordanian plant species. Food Chemistry. 2007; 104(4): 1372-1378.
29. Sanchez-Rangel JC, Benavides J, Heredia JB, Cisneros-Zevallos $\mathrm{L}$, and Jacobo-Velasquez DA. The Folin-Ciocalteu assay revisited: improvement of its specificity for total phenolic content determination. Analytical Methods. 2013; 21: 1-10.

30. Falleh $\mathrm{H}$, Ksouri $\mathrm{R}$, Lucchessi ME, Abdelly $\mathrm{C}$, and Magné $\mathrm{C}$. Ultrasound-assisted extraction: Effect of extraction time and solvent power on the levels of polyphenols and antioxidant activity of Mesembryanthemum edule L. Aizoaceae Shoots. Tropical Journal of Pharmaceutical Research. 2012; 11(2): 243-249.

31. Filip S, Pavli B, Vidovi S, Vladi J, and Zekovi Z. Optimization of microwave-assisted extraction of polyphenolic compounds from Ocimum basilicum by response surface methodology. Food Anaytical Methods. 2017; 2017: 1-11.

32. Yin-Leng $K$ and Suyin G. Natural deep eutectic solvent (NADES) as a greener alternative for the extraction of hydrophilic (polar) and lipophilic (non-polar) phytonutrients. Key Engeneering Materials. 2019; 797: 20-28.

33. Lu W, Alam MA, Pan Y, Wu J, Wang Z, and Yuan Z. A new approach of microalgal biomass pretreatment using deep eutectic solvents for enhanced lipid recovery for biodiesel production. Bioresources Technology. 2016; 218: 123-128.

34. Fernández M de los Á, Espino M, Gomez FJV, and Silva MF. Novel approaches mediated by tailor-made green solvents for the extraction of phenolic compounds from agro-food industrial byproduct. Food Chemistry. 2017; 239: 671-678.

35. Wang H, Ma X, Cheng O, Xi X, and Zhang L. Deep eutectic solventbased microwave-assisted extraction of Baicalin from Scutellaria baicalensis Georgi. Journal of Chemistry. 2018; 2018: 1-10

36. Ma W, Lu Y, Hu R, Chen J, Zhang Z, and Pan Y. Application of ionic liquids based microwave-assisted extraction of three alkaloids $\mathrm{N}$-nornuciferine, O-nornuciferine, and nuciferine from lotus leaf. Talanta. 2010; 80(3): 1292-1297.

37. Ahmad I, Yanuar A, Mulia K, and Mun'im A. Ionic liquid-based microwave-assisted extraction: Fast and green extraction method of secondary metabolites on medicinal plant. Pharmacognosy Reviews. 2018; 12(23): 20-26.

38. Cheng Z, Song $H$, Yang $Y$, Liu $Y$, Liu Z, Hu H, and Zhang $Y$. Optimization of microwave-assisted enzymatic extraction of polysaccharides from the fruit of Schisandra chinensis Baill. International Journal of Biological Macromolecules. 2015; 76: 161-168.

39. Handayani D, Mun'im A, and Ranti AS. Optimation of green tea waste axtraction using microwave assisted extraction to yield green tea extract. Traditional Medicine Journal. 2014; 19(1): 29-35.

40. Xiong W, Chen X, Lv G, Hu D, Zhao J, and Li S. Optimization of microwave-assisted extraction of bioactive alkaloids from lotus plumule using response surface methodology. Journal of Pharmaceutical Analysis. 2016; 6(6): 382-388. 


\section{GRAPHICAL ABSTRACT}

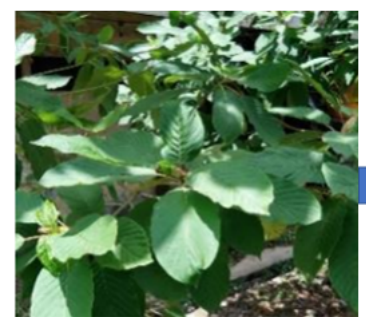

Mitraguna speciosa Korth Havil

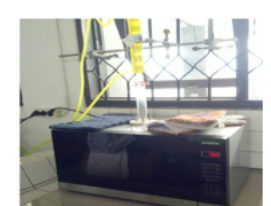

NADES-MAE Methods
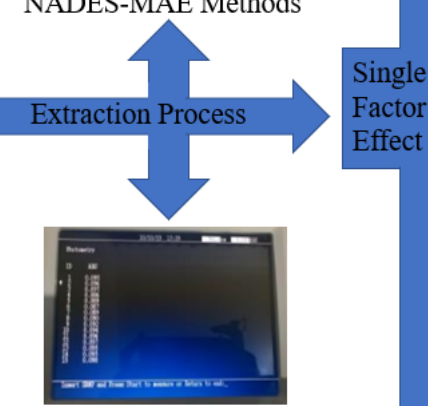

Total Polyphenolic Content (TPC)

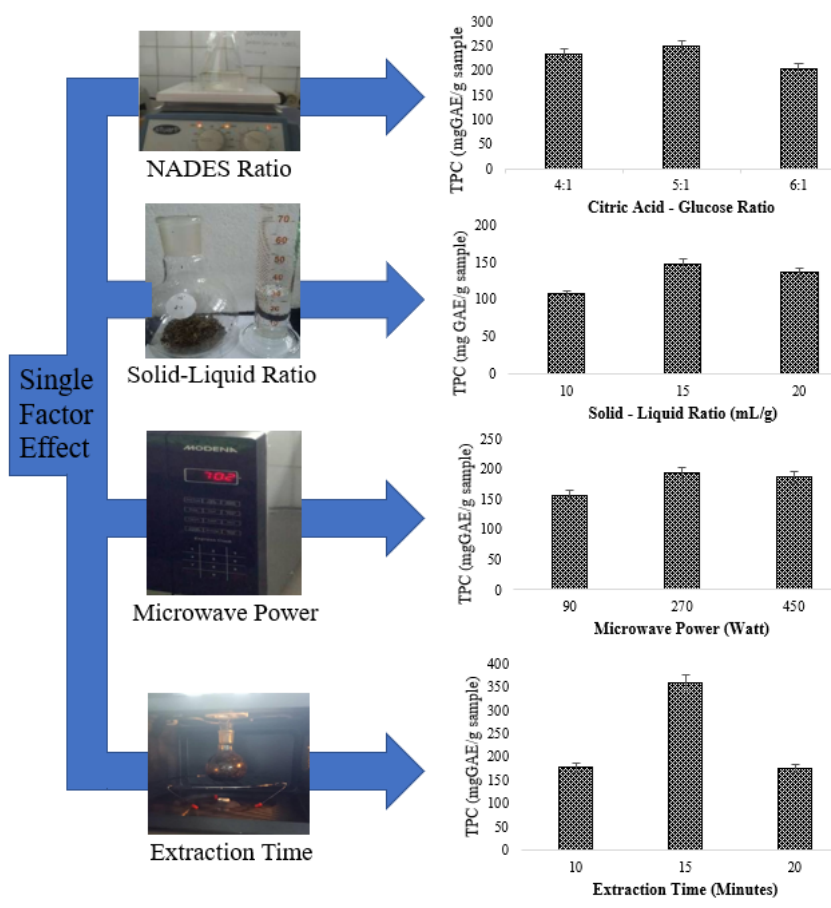

\section{SUMMARY}

1. The best of single factor condition effect of NADE-MAE method was obtained the TPC value including:

- NADES ratio of $248.69 \mathrm{mg} \mathrm{GAE} / \mathrm{g}$ sample (5:1 $\mathrm{g} / \mathrm{g}$ citric acid-glucose)

- A solid-liquid ratio of $146.93 \mathrm{mg} \mathrm{GAE} / \mathrm{g}$ sample (15:1 mL/g solvent-sample)

- Microwave power of $192.20 \mathrm{mg} \mathrm{GAE} / \mathrm{g}$ sample (270 Watts)

- Extraction time of $358.59 \mathrm{mg} \mathrm{GAE} / \mathrm{g}$ sample (15 min).

2. The single factor effect of NADES citric acid-glucose-based MAE shows a difference in TPC value based on various conditions of the NADES-MAE method.

\section{ABOUT AUTHORS}

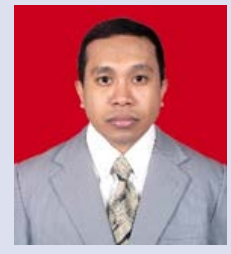

Dr. Herman, a lecturer, and researcher at Department of Pharmaceutical Sciences, Faculty of Pharmacy, Universitas Mulawarman, Samarinda, East Kalimantan, Indonesia. Research interest in medicinal chemistry, Pharmaceutical Analysis, and natural product chemistry.

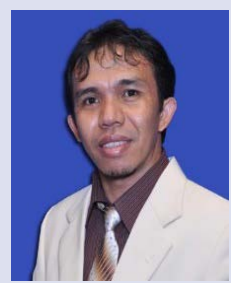

Arsyik Ibrahim, a doctoral candidate at Faculty of Pharmacy, Universitas Airlangga, Surabaya, East Java, Indonesia. As a lecturer and researcher at the Department of Pharmaceutical Sciences, Faculty of Pharmacy, Mulawarman University, East Kalimantan, Indonesia, he has experience in Pharmacognosy and Natural Products, working to search and discover drugs from nature, identification, and screening of anti-cancer and active antimicrobial. 


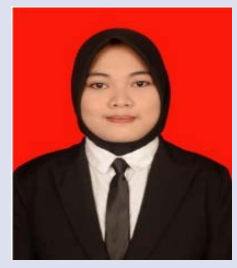

Bakti Puji Rahayu, an undergraduate student at the Faculty of Pharmacy, Universitas Mulawarman. Research interest in natural product chemistry.

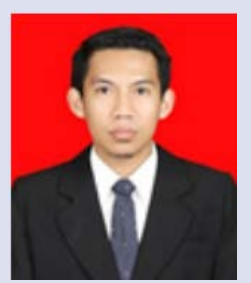

M. Arifuddin, a lecturer and researcher at Department of Pharmaceutical Sciences, Faculty of Pharmacy, Universitas Mulawarman, Samarinda, East Kalimantan, Indonesia. He has an interest in natural products and microbiology, especially isolation compound of endofit fungi from plants.

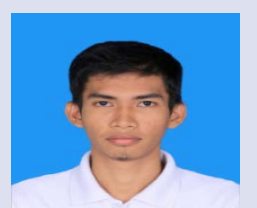

Yuspian Nur, a doctoral candidate at the Department of Chemistry, Faculty of Mathematics and Natural Sciences, Universitas Padjadjaran, Bandung, West Java, Indonesia. As a lecturer and researcher at the Faculty of Pharmacy, Universitas Mulawarman. Research interest in the development of sensor and biosensors, also focusing on analytical chemistry.

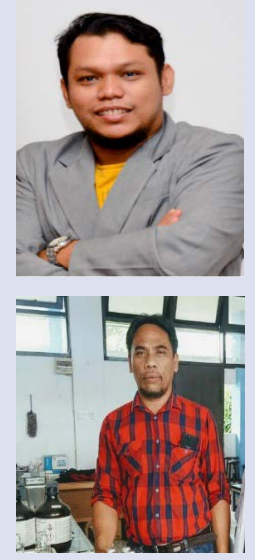

Wisnu Cahyo Prabowo, a doctoral student at the Department of Pharmaceutical Sciences, Faculty of Pharmacy, Universitas Padjadjaran, Bandung, West Java, Indonesia. As a lecturer and researcher at Faculty of Pharmacy, Universitas Mulawarman, Samarinda, East Kalimantan Indonesia. Research interest in Natural Products.

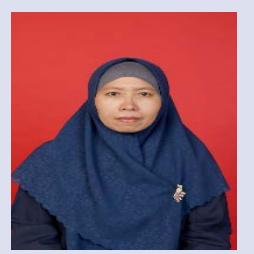

Dr. Neneng Siti Silfi Ambarwati, a Lecturer and Researcher at Cosmetology Department, Faculty of Engineering, Universitas Negeri Jakarta, East Jakarta, Indonesia. The research focused on natural products for drug and cosmetic discovery and development, extraction technology, and cosmetic ingredients (cosmeceuticals).

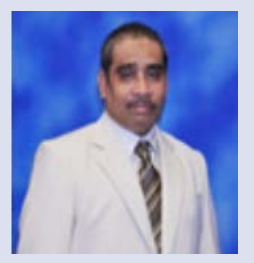

Prof. Dr. Laode Rijai, Professor at Department of Pharmaceutical Sciences and Dean at Faculty of Pharmacy, Universitas Mulawarman, Samarinda, East Kalimantan, Indonesia. He has experience in the area of Natural products and Organic Chemistry.

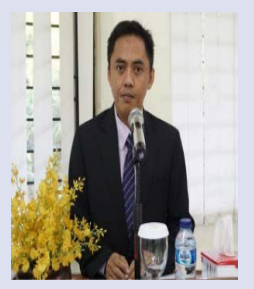

Maryono, a doctoral candidate at Postgraduate Program, Faculty of Pharmacy, Universitas Hasanuddin, Makassar, South Sulawesi, Indonesia. As a lecturer and researcher at the Department of Chemistry, Faculty of Mathematics and Natural Sciences, Universitas Negeri Makassar. Research interest in Natural Products Chemistry

Dr. Islamudin Ahmad, Associate Professor at Department of Pharmaceutical Sciences, Faculty of Pharmacy, Universitas Mulawarman, East Kalimantan, Indonesia. He has experience in Pharmacognosy and Natural Product Chemistry, working in drug discovery of natural products, green extraction engineering, isolation and identification of active compounds, screening activity, and mainly degenerative diseases 